\title{
Efficient synthesis of 1,8-dioxo-octahydroxanthenes catalyzed by $\beta$-cyclodextrin grafted with butyl sulfonic acid in aqueous media
}

\author{
Kai Gong a,*, Hualan Wang b, Shuxin Wang a , Ying Wang a, Jinghua Chen a \\ a School of Pharmaceutical Science, Jiangnan University, Wuxi 214122, Jiangsu, China \\ ${ }^{\mathrm{b}}$ Key Laboratory of Organosilicon Chemistry and Material Technology, Ministry of Education, Hangzhou Normal University, Hangzhou 311121, Zhejiang, \\ China
}

\section{A R T I C L E I N F O}

Article history:

Received 7 April 2015

Accepted 9 May 2015

Published 20 August 2015

\section{Keywords:}

One-pot synthesis

Acidic catalyst

$\beta$-Cyclodextrin bearing butyl sulfonic

acid

1,8-Dioxo-octahydroxanthenes

Aqueous media

\section{A B S T R A C T}

$\beta$-Cyclodextrin was functionalized with butyl sulfonic acid to give an efficient, eco-friendly catalyst for the synthesis of 1,8-dioxo-octahydroxanthenes via the one-pot condensation of aromatic aldehydes and active methylene carbonyl compounds in aqueous media. This new methodology offers several advantages such as excellent yields, short reaction time, a simple procedure and mild reaction conditions. Furthermore, the catalyst can be readily recovered and reused up to five times without a significant loss in its activity.

(C) 2015, Dalian Institute of Chemical Physics, Chinese Academy of Sciences. Published by Elsevier B.V. All rights reserved.

\section{Introduction}

Xanthenes and its derivatives have received considerable attention owing to their interesting pharmacological properties, including their anti-bacterial [1], antiviral [2] and anti-inflammatory activities [3]. As well as their pharmacological properties, xanthenes have also been widely used as dyes [4], as well as additives in $\mathrm{pH}$-sensitive fluorescent materials [5] and laser technologies [6]. In particular, xanthenediones constitute a structural unit that can be found in a large number of natural products [7]. Compounds belonging to this structural class have been used as versatile synthons for the synthesis of complex systems because of the inherent reactivity of their inbuilt pyran ring [8]. In light of their wide range of pharmaco- logical, industrial and synthetic applications, many methods for the preparation of xanthenes and xanthenediones have been reported in the literature [9].

One of the most commonly used methods reported for the synthesis of 1,8-dioxo-octahydroxanthene derivatives involves the condensation of aromatic aldehydes and active methylene carbonyl compounds. This reaction can be carried out in the presence of a protic acid or Lewis acid, such as $p$-dodecylbenzenesulfonic acid [10], Amberlyst-15 [11], $\mathrm{Fe}^{3+}$-montmorillonite [12], $\mathrm{HClO}_{4}-\mathrm{SiO}_{2}$ [13], $\mathrm{SiO}_{2}$ [14], nano-TiO2 [15], [Et $\left.{ }_{3} \mathrm{NH}\right]\left[\mathrm{HSO}_{4}\right]$ [16], I2 [17], L-proline [18], $\mathrm{CaCl}_{2}$ or $\mathrm{HBr}$ [19], nanosized MCM-41- $\mathrm{SO}_{3} \mathrm{H}$ [20], ceric ammonium nitrate-supported HY-zeolite [21], $\mathrm{Fe}_{3} \mathrm{O}_{4} @ \mathrm{SiO}_{2}$-imid- $\mathrm{H}_{3} \mathrm{PMo}_{2} \mathrm{O}_{40}$ nanoparticles [22] and cellulose sulfonic acid [23]. Xanthenediones

\footnotetext{
* Corresponding author. Tel/Fax: +86-510-85197769; E-mail: kingong222@163.com

This work was supported by the National Natural Science Foundation of China (51303069) and the Fundamental Research Funds for the Central Universities (JUSRP11236). 
have also been synthesized under microwave [24] and ultrasound [20] irradiation conditions. However, the general usefulness of these methods has been limited by several disadvantages, such as low yields, difficulties associated with the availability or preparation of the starting materials, prolonged reaction times, the use of toxic organic solvents, the requirement for a large excess of reagents or catalysts and harsh reaction conditions. The development of simple, efficient, highyielding and environmentally friendly methods for the synthesis of xanthenes using novel catalysts is therefore still in great demand.

The level of interest in the exploration of catalytic reactions in aqueous media has been increasing dramatically during the last few years because of advantages associated with performing reactions in water, such as improved reactivity and selectivity characteristics. Performing reactions in water can also lead to simplified workup procedures, making it easier to recycle the catalyst, as well as allowing for the use of mild reaction conditions [25]. Hence, considerable research efforts have been directed towards the design of novel ligands/catalysts to promote aqueous organic transformations. One of the most commonly used methods reported for the synthesis of phase transfer catalysts involves the combination of efficient homogeneous ligands/catalysts with water-soluble polymers (polyethylene glycol) or salts (sulfonate salt or quaternary ammonium salt) [26-30]. In this regard, cyclodextrin (CD) has received a particularly high level of attention because of its excellent water solubility and special hydrophobic cavity. Indeed, CDs and their derivatives have shown excellent performance characteristics in a broad range of aqueous organic reactions, including oxidation, cycloaddition, coupling and hydroformylation reactions [31-36]. In our group, we are especially interested in the use of CDs as catalyst supports and the use of these supported catalysts in aqueous biphasic reactions.

In this context, we wish to report the synthesis of a functionalized $\beta$-cyclodextrin bearing butyl sulfonic acid $(\beta$-CD-BSA $)$ groups and the subsequent application of this material as a catalyst for the synthesis of 1,8-dioxo-octahydroxanthenes (3) by the one-pot condensation of various aldehydes (1) with dimedone (2a) or 1,3-cyclohexanedione (2b) in aqueous media (Scheme 1). To the best of our knowledge, the work described in this study represents the first reported example of the synthesis of $\beta$-CD-BSA and its use as a catalyst for the preparation of 1,8-dioxo-octahydroxanthenes.

\section{Experimental}

\subsection{General}

All of the reagents used in the current study were purchased from commercial sources and used without further purification. Melting points were determined on an X6-data microscopic melting points apparatus and were uncorrected. Fourier transform infrared (FT-IR) spectra were recorded on a Bruker Vecter 22 spectrometer as $\mathrm{KBr}$ disks. ${ }^{1} \mathrm{H}$ and ${ }^{13} \mathrm{C}$ NMR spectra were recorded on a Bruker Avance III (400 MHz) spectrometer using $\mathrm{D}_{2} \mathrm{O}$ or $\mathrm{CDCl}_{3}$ as a solvent with TMS as internal reference

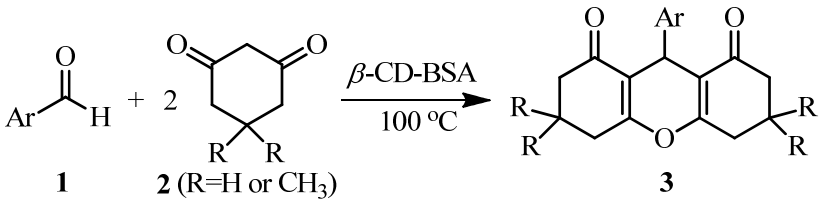

Scheme 1. Synthesis of 1,8-dioxo-octahydroxanthenes.

standard.

\subsection{Synthesis of $\beta$ - $C D-B S A$}

$\beta$-CD (2 g) was dissolved in a solution of $\mathrm{NaOH}(20 \mathrm{~mL}, 5$ mol/L), and the resulting solution was heated at $75{ }^{\circ} \mathrm{C}$. 1,4-Butane sultone ( $2.4 \mathrm{~g}$ ) was then added to the reaction in a dropwise manner, and the resulting mixture was stirred for $3 \mathrm{~h}$ at $75{ }^{\circ} \mathrm{C}$. The reaction was then cooled to room temperature and the $\mathrm{pH}$ was adjusted to neutral using a $\mathrm{HCl}$ solution (3 mol/L). The neutral mixture was then dropped into ethanol to afford sulfobutyl ether $\beta$-cyclodextrin (SBE- $\beta$-CD) as a white solid, which was collected by filtration.

Acidic resin was activated in a saturated aqueous solution of $\mathrm{NaCl}$ for $24 \mathrm{~h}$, treated with an aqueous solution of $\mathrm{NaOH}(2.5$ wt $\%$ ) for $80 \mathrm{~min}$, washed with distilled water until the $\mathrm{pH}$ of the washings reached 7.0 and then treated with an aqueous solution of $\mathrm{HCl}(5.0 \mathrm{wt} \%)$ for $12 \mathrm{~h}$. After this treatment process, the resin was transferred to a column and washed with deionized water until the $\mathrm{pH}$ of the eluent reached 7.0.

A portion of the sodium salt of SBE- $\beta$-CD $(1.0 \mathrm{~g})$ was dissolved in water $(100 \mathrm{~mL})$, and the resulting solution was allowed to flow through the acidic resin column at a speed of 20 drops/min. The acidic eluent was then collected and freeze-dried for $12 \mathrm{~h}$ to the give the $\beta$-CD-BSA product.

IR ( $\mathrm{KBr}, \mathrm{cm}^{-1}$ ): 3454, 3419, 2963, 2924, 2361, 2342, 1655, 1636, 1613, 1383, 1217, 1192, 1136, 1051, 818, 705, 689, 612, 560. ${ }^{1} \mathrm{H} \quad \mathrm{NMR} \quad\left(400 \quad \mathrm{MHz}, \mathrm{D}_{2} \mathrm{O}\right): \quad \delta \quad 1.70 \quad(\mathrm{~m}$, $\left.-\mathrm{OCH}_{2} \mathrm{CH}_{2} \mathrm{CH}_{2} \mathrm{CH}_{2} \mathrm{SO}_{3} \mathrm{H}\right), 2.88\left(\mathrm{~m},-\mathrm{OCH}_{2} \mathrm{CH}_{2}-\mathrm{CH}_{2} \mathrm{CH}_{2} \mathrm{SO}_{3} \mathrm{H}\right)$, 3.49-3.8 (m, $-\mathrm{OCH}_{2}-\mathrm{CH}_{2} \mathrm{CH}_{2} \mathrm{CH}_{2} \mathrm{SO}_{3} \mathrm{H}$ and $\mathrm{CH}$ ), 5.01-5.14 (m, $\left.\mathrm{C}_{1}-\mathrm{H}\right)$.

\subsection{Typical procedure for the synthesis of 1,8-dioxo-octahydroxanthenes}

A mixture of aromatic aldehyde $\mathbf{1}$ ( $2 \mathrm{mmol}$ ), 5,5-dimethyl1,3-cyclo-hexanedione or 1,3-cyclohexanedione (4 mmol) and $\beta$-CD-BSA ( $1 \mathrm{~mol} \%$ ) in $\mathrm{H}_{2} \mathrm{O}(2 \mathrm{~mL})$ was stirred at $100{ }^{\circ} \mathrm{C}$ for the appropriate length of time. Upon completion of the reaction, as determined by TLC, the resulting solid material was filtered and washed with $\mathrm{H}_{2} \mathrm{O}(10 \mathrm{~mL})$. The crude products were purified by recrystallization from EtOH (95\%).

Analytical data for selected compounds are presented below.

Compound 3a: white crystals, mp $202-204{ }^{\circ} \mathrm{C}\left(204-205^{\circ} \mathrm{C}\right.$ [12]). FT-IR (KBr, cm${ }^{-1}$ ): 3427, 2958, 2915, 2870, 1662, 1625, 1578, 1468, 1454, 1382, 1361, 1202, 1166, 1154, 1141, 1127, 1002, 700; ${ }^{1} \mathrm{H}$ NMR (400 MHz, $\left.\mathrm{CDCl}_{3}\right): \delta 0.99\left(\mathrm{~s}, 6 \mathrm{H}, \mathrm{CH}_{3}\right), 1.10$ (s, 6H, $\mathrm{CH}_{3}$ ), 2.14-2.25 (m, 4H, $\left.\mathrm{CH}_{2}\right), 2.47$ (s, $\left.4 \mathrm{H}, \mathrm{CH}_{2}\right), 4.75$ (s, 
$1 \mathrm{H}, \mathrm{CH}), 7.08-7.12(\mathrm{t}, 1 \mathrm{H}, \mathrm{ArH}), 7.19-7.23(\mathrm{t}, 2 \mathrm{H}, \mathrm{ArH})$, 7.28-7.30 (d, 2H, ArH); ${ }^{13} \mathrm{C}$ NMR (100 MHz, $\mathrm{CDCl}_{3}$ ): $\delta 196.42$, $162.26,144.11,128.40,128.07,126.39,115.68,50.75,40.88$, $32.23,31.85,29.31,27.35$.

Compound 3i: white crystals, mp $217-219^{\circ} \mathrm{C}\left(216-218{ }^{\circ} \mathrm{C}\right.$ [13]). FT-IR (KBr, cm-1): 3444, 2962, 2874, 1677, 1625, 1511, $1468,1412,1391,1360,1198,1166,1140,1126,1001,840 ;{ }^{1} \mathrm{H}$ NMR (300 MHz, CDCl $): \delta 0.99\left(\mathrm{~s}, 6 \mathrm{H}, \mathrm{CH}_{3}\right), 1.10\left(\mathrm{~s}, 6 \mathrm{H}, \mathrm{CH}_{3}\right)$, 2.14-2.25 (m, 7H, $\mathrm{CH}_{2}$ and $\left.\mathrm{Ar}-\mathrm{CH}_{3}\right), 2.45$ (s, 4H, CH), $4.71(\mathrm{~s}, 1 \mathrm{H}$, $\mathrm{CH}), 7.02(\mathrm{~d}, J=8.0 \mathrm{~Hz}, 2 \mathrm{H}, \mathrm{ArH}), 7.17$ (d, $J=8.0 \mathrm{~Hz}, 2 \mathrm{H}, \mathrm{ArH})$; ${ }^{13} \mathrm{C}$ NMR $\left(100 \mathrm{MHz}, \mathrm{CDCl}_{3}\right): \delta 196.45,162.11,141.21,135.79$, 128.81, 128.26, 115.78, 50.78, 40.89, 32.23, 31.45, 29.30, 27.40, 21.09 .

Compound 3u: yellow crystals, mp $286-287^{\circ} \mathrm{C}$. FT-IR $(\mathrm{KBr}$, $\mathrm{cm}^{-1}$ ): 3428, 2923, 2850, 1659, 1606, 1591, 1521, 1423, 1384, $1361,1347,1174,1128 ;{ }^{1} \mathrm{H}$ NMR (400 MHz, $\left.\mathrm{CDCl}_{3}\right): \delta 1.94-2.11$ (m, $4 \mathrm{H}, \mathrm{CH}_{2}$ ), 2.34-2.37 (m, 4H, $\left.\mathrm{CH}_{2}\right), 2.57-2.73\left(\mathrm{~m}, 4 \mathrm{H}, \mathrm{CH}_{2}\right)$, $4.88(\mathrm{~s}, 1 \mathrm{H}, \mathrm{CH}), 7.48$ (d, $J=8.0 \mathrm{~Hz}, 2 \mathrm{H}, \mathrm{ArH}), 8.09$ (d, $J=8.0 \mathrm{~Hz}$, $2 \mathrm{H}, \mathrm{ArH}) ;{ }^{13} \mathrm{C}$ NMR $\left(100 \mathrm{MHz}, \mathrm{CDCl}_{3}\right): \delta 196.46,164.59,151.73$, $146.48,129.44,123.46,115.77,36.83,32.23,27.16,20.24$.

Compound 3y: yellow crystals, mp 288-290 ${ }^{\circ} \mathrm{C}$. FT-IR (KBr, $\mathrm{cm}^{-1}$ ): 3382, 2949, 1662, 1610, 1597, 1515, 1446, 1430, 1387, $1361,1275,1242,1207,1193,1172,1130,961,835,632,609$; ${ }^{1} \mathrm{H}$ NMR (400 MHz, $\left.\mathrm{CDCl}_{3}\right): \delta 1.97-2.07\left(\mathrm{~m}, 4 \mathrm{H}, \mathrm{CH}_{2}\right), 2.28-2.41$ (m, 4H, $\left.\mathrm{CH}_{2}\right), 2.56-2.67\left(\mathrm{~m}, 4 \mathrm{H}, \mathrm{CH}_{2}\right), 4.74(\mathrm{~s}, 1 \mathrm{H}, \mathrm{CH}), 4.81$ (bs, $1 \mathrm{H}, \mathrm{Ar}-\mathrm{OH}$ ), 6.67 (d, J = 8.0 Hz, 2H, ArH), 7.16 (d, $J=8.0 \mathrm{~Hz}, 2 \mathrm{H}$, $\mathrm{ArH}) ;{ }^{13} \mathrm{C}$ NMR $\left(100 \mathrm{MHz}, \mathrm{CDCl}_{3}\right): \delta 196.77,163.79,154.05$, $136.84,129.57,117.07,115.02,36.99,30.79,27.15,20.33$.

\section{Results and discussion}

A schematic illustration of the steps involved in the preparation for $\beta$-CD-BSA is shown in Scheme 2. Briefly, commercially available $\beta$-CD was reacted with 1,4-butane sultone in a $\mathrm{NaOH}$ solution to afford sulfobutyl ether $\beta$-cyclodextrin, which was treated with acidic resin to give $\beta$-CD-BSA. The resulting $\beta$-CD-BSA material was characterized by FT-IR spectroscopy and ${ }^{1} \mathrm{H}$ NMR. The average degree of substitution for the sulfobutyl ether group on the $\beta$-CD-BSA material was found to be 7 [37].

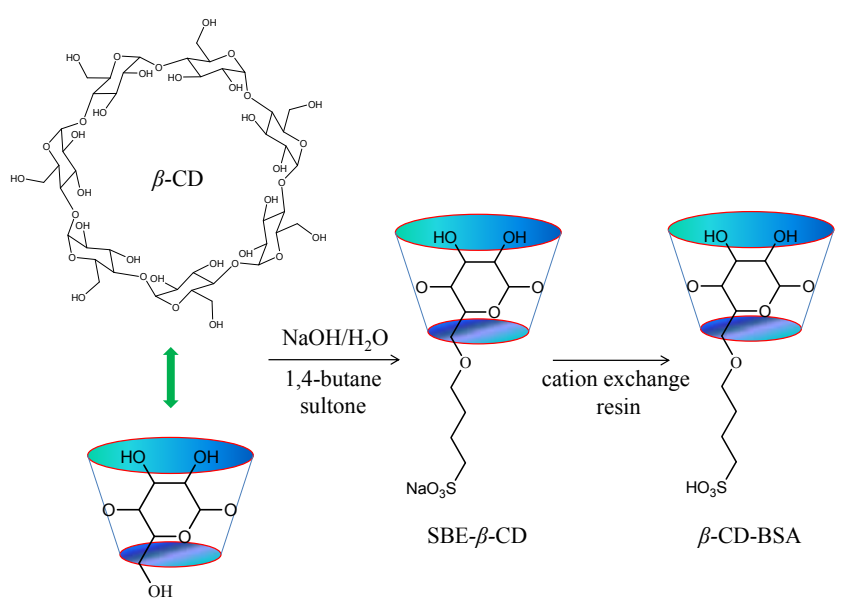

Scheme 2. Synthesis of $\beta$-CD-BSA.
The reaction of benzaldehyde (1a) with dimedone (2a) was initially selected as a model reaction to optimize the reaction conditions for the formation of 1,8-dioxo-octahydroxanthenes using a variety of solvents, temperatures, reactions times and catalyst loadings. The results of these optimization experiments are summarized in Table 1 . These results showed that none of the desired 1,8-dioxo-octahydroxanthene product was detected when a mixture of benzaldehyde and dimedone was heated at $100{ }^{\circ} \mathrm{C}$ for $120 \mathrm{~min}$ in the absence of the catalyst (Table 1, entry 1). Furthermore, no activity was observed in the presence of $\beta$-CD (Table 1 , entry 2). When SBE- $\beta$-CD was used as the catalyst, the product was obtained in low yield (Table 1, entry 3 ). Pleasingly, however, the use of a small amount of $\beta$-CD-BSA as the catalyst gave the desired product in excellent yield over a much shorter reaction time (Table 1, entry 4). The best result was achieved when the reaction was carried out with a $1 \mathrm{~mol} \%$ loading of $\beta$-CD-BSA (Table 1 , entry 5 ). The use of a higher loading of the catalyst did not lead to further improvements in the yield or reaction time (Table 1, entry 6).

The results of the optimization experiments indicated that the nature of the solvent had a significant impact on the outcome of the reaction (Table 1, entries 7-14). It is noteworthy that the use of a non-polar solvent such as toluene or cyclohexane gave moderate yields of the desired product $65 \%$ and $70 \%$, respectively). The use of a polar aprotic solvent such as THF or MeCN led to a slight improvement in the yield (76\% and $85 \%$, respectively). In the absence of a solvent, the reaction proceeded smoothly to give the desired product in a yield of $86 \%$, although an extended reaction time of $60 \mathrm{~min}$ was required. Performing the reaction in a polar solvent therefore afforded improved yields of the product as well as enhancing the reaction rate. The use of polar protic solvents such as water and ethanol accelerated the reaction within a minimum reaction time at $100{ }^{\circ} \mathrm{C}$ to give the desired product 3a in $93 \%$ and $91 \%$ yields, respectively. According to the principles of green chemistry, water was selected as the best reaction medium for further evaluation. Based on these experiments, the optimal

Table 1

Optimization of the reaction conditions for the synthesis of 3a.

\begin{tabular}{lccccc}
\hline Entry & Solvent & $\begin{array}{c}T \\
\left({ }^{\circ} \mathrm{C}\right)\end{array}$ & $\begin{array}{c}\text { Catalyst } \\
(\mathrm{mol} \%)\end{array}$ & $\begin{array}{c}\text { Time } \\
(\mathrm{min})\end{array}$ & $\begin{array}{c}\text { Yield } \\
(\%)\end{array}$ \\
\hline 1 & $\mathrm{H}_{2} \mathrm{O}$ & 100 & 0 & 120 & $\mathrm{NR}^{\mathrm{b}}$ \\
2 & $\mathrm{H}_{2} \mathrm{O}$ & 100 & $\beta$-CD (1) & 30 & $\mathrm{NR}^{\mathrm{b}}$ \\
3 & $\mathrm{H}_{2} \mathrm{O}$ & 100 & SBE- $\beta$-CD (1) & 30 & 56 \\
4 & $\mathrm{H}_{2} \mathrm{O}$ & 100 & $\beta$-CD-BSA (0.5) & 30 & 85 \\
5 & $\mathrm{H}_{2} \mathrm{O}$ & 100 & $\beta$-CD-BSA (1) & 30 & 93 \\
6 & $\mathrm{H}_{2} \mathrm{O}$ & 100 & $\beta$-CD-BSA (2) & 30 & 93 \\
7 & - & 100 & $\beta$-CD-BSA (1) & 60 & 86 \\
8 & Toluene & 100 & $\beta$-CD-BSA (1) & 100 & 65 \\
9 & $\mathrm{Cyclohexane}$ & Reflux & $\beta$-CD-BSA (1) & 100 & 70 \\
10 & $\mathrm{THF}$ & Reflux & $\beta$-CD-BSA (1) & 60 & 76 \\
11 & $\mathrm{MeCN}_{12}$ & Reflux & $\beta$-CD-BSA (1) & 60 & 85 \\
13 & $\mathrm{DMF}_{3} \mathrm{CH}_{2} \mathrm{OH}$ & 100 & $\beta$-CD-BSA (1) & 60 & 82 \\
14 & $\mathrm{HOCH}_{2} \mathrm{CH} \mathrm{H}_{2} \mathrm{OH}$ & 100 & $\beta$-CD-BSA (1) & 30 & 91 \\
\hline
\end{tabular}

Reaction conditions: benzaldehyde $(2 \mathrm{mmol})$, dimedone $(4 \mathrm{mmol})$, solvent-free or solvent $(2 \mathrm{~mL})$.

a Isolated yield.

${ }^{\mathrm{b}}$ No reaction was observed. 
reaction conditions for the formation of 1,8-dioxo-octahydroxanthenes were determined to be $1 \mathrm{~mol} \%$ of the $\beta$-CD-BSA catalysts in water at $100{ }^{\circ} \mathrm{C}$.

To assess the efficiency and the generality of the catalyst, we applied the optimal protocol to a variety of substituted aromatic aldehydes and active methylene carbonyl compounds, and the results of these experiments are summarized in Table 2. It revealed that aromatic aldehydes bearing an electron-donating or electron-withdrawing substituent reacted smoothly with dimedone or 1,3-cyclohexanedione to give the corresponding 1,8-dioxo-octahydroxanthene products in high yields. The results also showed that aromatic aldehydes bearing electron-withdrawing groups reacted at a greater rate to give higher yields of the 1,8-dioxo-octahydroxanthene products than those bearing electron-donating groups.

The efficiency of our newly synthesized catalyst for the synthesis of 1,8-dioxo-octahydroxanthenes was further evaluated by comparing its performance with several other catalysts reported in the literature. These comparison experiments were based on the synthesis of compounds $\mathbf{3 h}$ from 4-nitrobenzaldehyde and dimedone, and the results are listed in Table 3 . The results revealed that $\beta$-CD-BSA performed much more effectively than the other catalysts in terms of providing a very short reaction time, mild conditions and a high yield of the product.

Based on the results described above, we have proposed a plausible mechanism for the synthesis of 1,8-dioxo-octahydroxanthenes using the $\beta$-CD-BSA catalyst (Scheme 3 ). Considering the protic and acidic nature of $\beta$-CD-BSA, it was envisaged that one molecule of the enol tautomer of dimedone would be react with the activated aldehyde I to give the ortho-quinone methide (o-QMs) II via a Knoevenagel reaction. Intermediate II would then react with another molecule of dimedone via a Michael addition reaction to give intermediate III, which would undergo a cyclodehydration reaction to give the expected product 3. In this case, the $\beta$-CD-BSA material would not only function as a protic acid but would also perform as a phase transfer catalyst $[38,39]$.The $\beta$-CD-BSA material would therefore catalyze the reaction and participate in the formation of stable colloidal particles in the presence of the substrates in water, which would play an important role in accelerating the rate of the reaction. The formation of colloidal particles could be the main reason that $\beta$-CD-BSA exhibited such a high level of
Table 2

$\beta$-CD-BSA-catalyzed synthesis of 1,8-dioxo-octahydroxanthenes.

\begin{tabular}{|c|c|c|c|c|c|}
\hline Entry & $\mathrm{Ar}$ & $\mathrm{R}$ & Product & Time (min) & Yield a (\%) \\
\hline 1 & $\mathrm{C}_{6} \mathrm{H}_{5}$ & $\mathrm{CH}_{3}$ & $3 \mathbf{a}$ & 30 & 93 \\
\hline 2 & $2-\mathrm{Cl}-\mathrm{C}_{6} \mathrm{H}_{5}$ & $\mathrm{CH}_{3}$ & $3 \mathbf{b}$ & 30 & 94 \\
\hline 3 & $4-\mathrm{Cl}-\mathrm{C}_{6} \mathrm{H}_{5}$ & $\mathrm{CH}_{3}$ & $3 c$ & 20 & 97 \\
\hline 4 & $2,4-\mathrm{Cl}_{2}-\mathrm{C}_{6} \mathrm{H}_{5}$ & $\mathrm{CH}_{3}$ & 3d & 30 & 95 \\
\hline 5 & $4-\mathrm{F}-\mathrm{C}_{6} \mathrm{H}_{5}$ & $\mathrm{CH}_{3}$ & $3 e$ & 20 & 96 \\
\hline 6 & $2-\mathrm{NO}_{2}-\mathrm{C}_{6} \mathrm{H}_{5}$ & $\mathrm{CH}_{3}$ & $3 f$ & 25 & 96 \\
\hline 7 & $3-\mathrm{NO}_{2}-\mathrm{C}_{6} \mathrm{H}_{5}$ & $\mathrm{CH}_{3}$ & $3 g$ & 20 & 97 \\
\hline 8 & $4-\mathrm{NO}_{2}-\mathrm{C}_{6} \mathrm{H}_{5}$ & $\mathrm{CH}_{3}$ & $3 \mathbf{h}$ & 15 & 95 \\
\hline 9 & $4-\mathrm{CH}_{3}-\mathrm{C}_{6} \mathrm{H}_{5}$ & $\mathrm{CH}_{3}$ & $3 \mathbf{i}$ & 45 & 90 \\
\hline 10 & $4-\mathrm{CH}_{3} \mathrm{O}-\mathrm{C}_{6} \mathrm{H}_{5}$ & $\mathrm{CH}_{3}$ & $3 \mathbf{j}$ & 60 & 95 \\
\hline 11 & $4-\mathrm{OH}-\mathrm{C}_{6} \mathrm{H}_{5}$ & $\mathrm{CH}_{3}$ & $3 \mathbf{k}$ & 40 & 90 \\
\hline 12 & $2-\mathrm{OH}-\mathrm{C}_{6} \mathrm{H}_{5}$ & $\mathrm{CH}_{3}$ & $3 m$ & 40 & 88 \\
\hline 13 & $4-\mathrm{N}\left(\mathrm{CH}_{3}\right)_{2}-\mathrm{C}_{6} \mathrm{H}_{5}$ & $\mathrm{CH}_{3}$ & $3 n$ & 60 & 93 \\
\hline 14 & $\mathrm{C}_{6} \mathrm{H}_{5}$ & $\mathrm{H}$ & 31 & 30 & 88 \\
\hline 15 & $2-\mathrm{Cl}-\mathrm{C}_{6} \mathrm{H}_{5}$ & $\mathrm{H}$ & 30 & 20 & 95 \\
\hline 16 & $4-\mathrm{Cl}-\mathrm{C}_{6} \mathrm{H}_{5}$ & $\mathrm{H}$ & $3 p$ & 20 & 96 \\
\hline 17 & $2,4-\mathrm{Cl}_{2}-\mathrm{C}_{6} \mathrm{H}_{5}$ & $\mathrm{H}$ & $3 q$ & 20 & 90 \\
\hline 18 & $4-\mathrm{F}-\mathrm{C}_{6} \mathrm{H}_{5}$ & $\mathrm{H}$ & $3 \mathbf{r}$ & 20 & 93 \\
\hline 19 & $2-\mathrm{NO}_{2}-\mathrm{C}_{6} \mathrm{H}_{5}$ & $\mathrm{H}$ & $3 s$ & 20 & 92 \\
\hline 20 & $3-\mathrm{NO}_{2}-\mathrm{C}_{6} \mathrm{H}_{5}$ & $\mathrm{H}$ & $3 t$ & 15 & 92 \\
\hline 21 & $4-\mathrm{NO}_{2}-\mathrm{C}_{6} \mathrm{H}_{5}$ & $\mathrm{H}$ & $3 u$ & 15 & 94 \\
\hline 22 & $4-\mathrm{CH}_{3}-\mathrm{C}_{6} \mathrm{H}_{5}$ & $\mathrm{H}$ & $3 v$ & 45 & 91 \\
\hline 23 & $4-\mathrm{CH}_{3} \mathrm{O}-\mathrm{C}_{6} \mathrm{H}_{5}$ & $\mathrm{H}$ & $3 w$ & 60 & 95 \\
\hline 24 & $2-\mathrm{OH}-\mathrm{C}_{6} \mathrm{H}_{5}$ & $\mathrm{H}$ & $3 x$ & 60 & 90 \\
\hline 25 & $4-\mathrm{OH}-\mathrm{C}_{6} \mathrm{H}_{5}$ & $\mathrm{H}$ & $3 y$ & 60 & 92 \\
\hline 26 & $4-\mathrm{N}\left(\mathrm{CH}_{3}\right)_{2}-\mathrm{C}_{6} \mathrm{H}_{5}$ & $\mathrm{H}$ & $3 z$ & 60 & 90 \\
\hline
\end{tabular}

Reaction conditions: aldehyde (2 mmol), dimedone or 13 -cyclohexanedione ( $4 \mathrm{mmol}), \beta$-CD-BSA $(0.02 \mathrm{mmol}), \mathrm{H}_{2} \mathrm{O}(2 \mathrm{~mL}), 100{ }^{\circ} \mathrm{C}$.

a Isolated yield.

catalytic activity towards this reaction.

The ability of a catalyst to be recovered and reused is becoming increasingly important for the development of green processes. With this in mind, we evaluated the reusability of our newly developed catalyst using 4-nitrobenzaldehyde and dimedone as model substrates. After the separation of the products, the filtrate containing the catalyst was distilled to dryness under vacuum to allow for the removal of the water, and the resulting catalyst was used directly in the next run. As shown in Fig. 1, the results of these experiments revealed that the catalyst could be recycled up to five times without any significant decrease in the catalytic activity and yields in the range of $95 \%$ to $90 \%$.

Table 3

Comparison of different catalysts for the synthesis of $\mathbf{3 h}$.

\begin{tabular}{|c|c|c|c|c|c|}
\hline Entry & Catalyst & Condition & Time & Yield (\%) & Ref. \\
\hline 1 & $\beta$-CD-BSA & $\mathrm{H}_{2} \mathrm{O}$ & $15 \mathrm{~min}$ & 95 & This work \\
\hline 2 & DBSA & $\mathrm{H}_{2} \mathrm{O} / 100^{\circ} \mathrm{C}$ & $6 \mathrm{~h}$ & 94 & [10] \\
\hline 3 & {$\left[\mathrm{Et}_{3} \mathrm{NH}\right]\left[\mathrm{HSO}_{4}\right]$} & Solvent-free $/ 100^{\circ} \mathrm{C}$ & $30 \mathrm{~min}$ & 92 & [16] \\
\hline 4 & Cellulose sulfonic acid & Solvent-free $/ 110^{\circ} \mathrm{C}$ & $5 \mathrm{~h}$ & 95 & [23] \\
\hline 5 & MCM-41- $\mathrm{SO}_{3} \mathrm{H}$ & $\mathrm{H}_{2} \mathrm{O} / 90^{\circ} \mathrm{C}$ & $60 \mathrm{~min}$ & 50 & [20] \\
\hline 6 & $\mathrm{HClO}_{4}-\mathrm{SiO}_{2}$ & $\mathrm{H}_{2} \mathrm{O} / 100{ }^{\circ} \mathrm{C}$ & $1 \mathrm{~h}$ & 68.2 & [13] \\
\hline 7 & Amberlyst-15 & $\mathrm{CH}_{3} \mathrm{CN} /$ reflux & $5 \mathrm{~h}$ & 94 & [11] \\
\hline 8 & L-Proline & $\mathrm{ClCH}_{2} \mathrm{CH}_{2} \mathrm{Cl} / 60^{\circ} \mathrm{C}$ & $6 \mathrm{~h}$ & 78 & {$[18]$} \\
\hline 9 & $\mathrm{Fe}^{3+}$-montmorillonite & EtOH $/ 100^{\circ} \mathrm{C}$ & $6 \mathrm{~h}$ & 93 & [12] \\
\hline 10 & CAN supported HY-zeolite & Solvent-free $/ 80^{\circ} \mathrm{C}$ & $45 \mathrm{~min}$ & 93 & [21] \\
\hline 11 & $\mathrm{Fe}_{3} \mathrm{O}_{4} @ \mathrm{SiO}_{2}$-imid-PMA & EtOH/reflux & $1.25 \mathrm{~h}$ & 94 & [22] \\
\hline 12 & nano- $\mathrm{TiO}_{2}$ & Solvent-free $/ 100^{\circ} \mathrm{C}$ & $15 \mathrm{~min}$ & 96 & [15] \\
\hline 13 & $\mathrm{CaCl}_{2}$ & DMSO $/ 90^{\circ} \mathrm{C}$ & $5 \mathrm{~h}$ & 87 & [19] \\
\hline
\end{tabular}




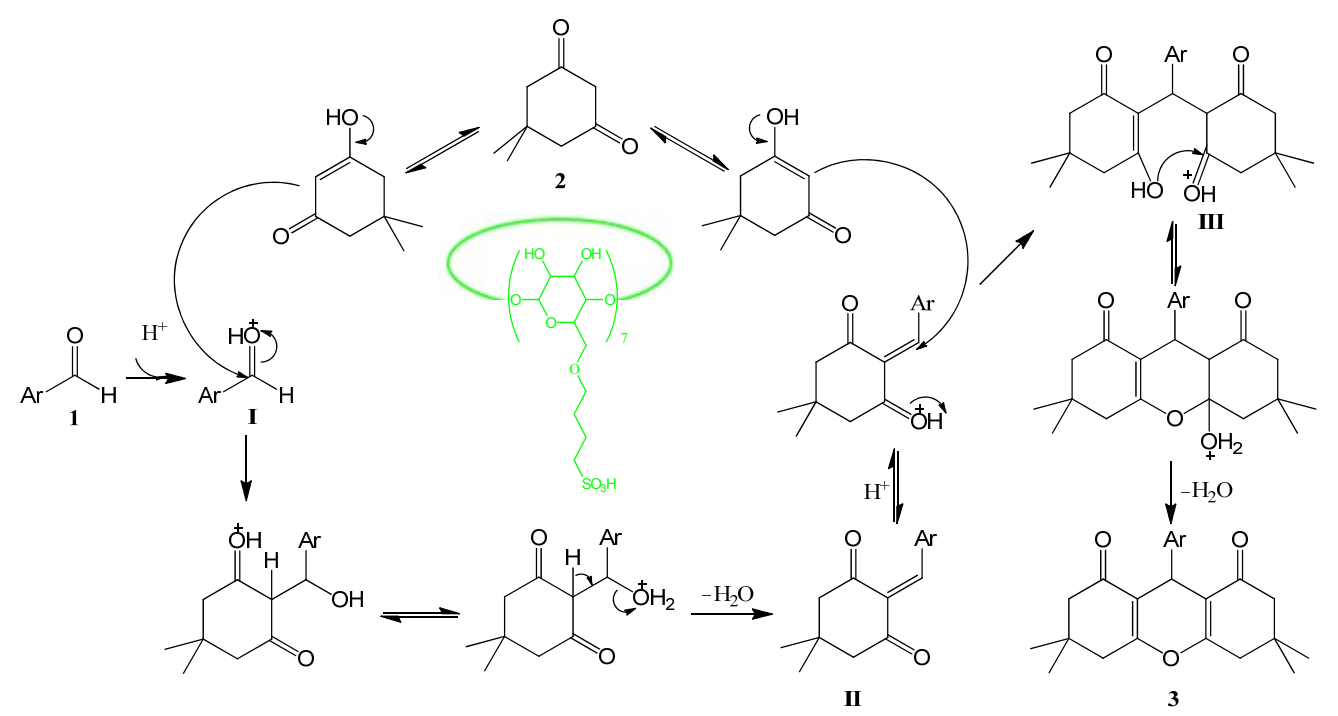

Scheme 3. Possible mechanism for the synthesis of 1,8-dioxo-octahydroxanthenes catalyzed by $\beta$-CD-BSA.

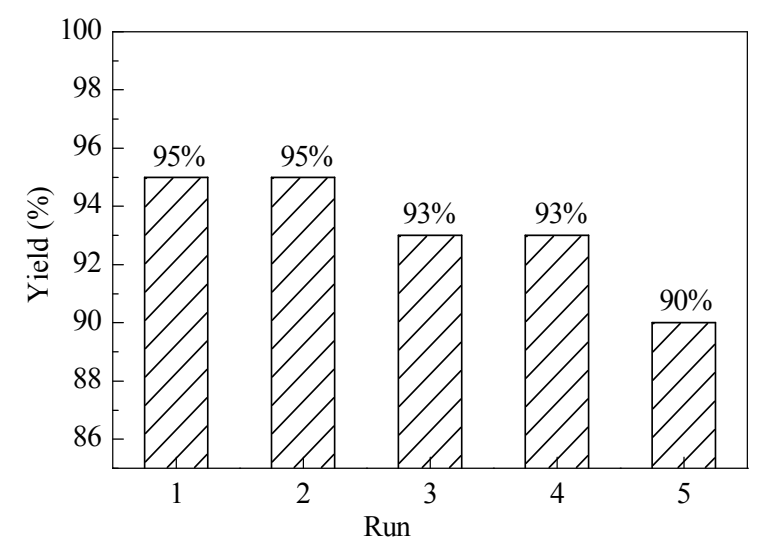

Fig. 1. Recyclability experiments using $\beta$-CD-BSA for the synthesis of 3h.

\section{Conclusions}

We have developed a novel eco-friendly procedure for the synthesis of 1,8-dioxo-octahydroxanthenes via the one-pot condensation of aromatic aldehydes and active methylene carbonyl compounds using $\beta$-CD-BSA as a catalyst. The attractive features of this new protocol include a simple procedure, high catalytic activity, short reaction time, excellent yields, recyclable catalyst and its adaptability for the synthesis of a diverse set of 1,8-dioxo-octahydroxanthenes. This approach therefore represents a valuable addition to the existing processes for the synthesis of benzoxanthenes.

\section{References}

[1] Zelefack F, Guilet D, Fabre N, Bayet C, Chevalley S, Ngouela S, Lenta B N, Valentin A, Tsamo E, Dijoux-Franca M G. J Nat Prod, 2009, 72: 954

[2] Wang H K, Morris-Natschke S L, Lee K H. Med Res Rev, 1997, 17: 367

[3] Poupelin J P, Saint-Ruf G, Foussard-Blanpin O, Narcisse G, Uchida-Ernouf G, Lacroix R. Eur J Med Chem, 1978, 13: 67
[4] Zolfigol M A, Moosavi-Zare A R, Arghavani-Hadi P, Zare A, Khakyzadeh V, Darvishi G. RSC Adv, 2012, 2: 3618

[5] Liu J, Diwu Z, Leung W Y. Bioorg Med Chem Lett, 2001, 11: 2903

[6] Ahmad M, King T A, Ko D K, Cha B H, Lee J.J Phys D, 2002, 35 : 1473

[7] Hatakeyma S, Ochi N, Numata H, Takano S. J Chem Soc, Chem Commun, 1988: 1202

[8] O'Callaghan C N, McMurry T B H. J Chem Res Synop, 1995: 214

[9] Li J J, Lu L M, Su W K. Tetrahedron Lett, 2010, 51: 2434

[10] Jin T S, Zhang J S, Xiao J C, Wang A Q Li T S. Synlett, 2004: 866

[11] Das B, Thirupathi P, Mahender I, Reddy V S, Rao Y K.J Mol Catal A, 2006, 247: 233

[12] Song G Y, Wang B, Luo H T, Yang L M. Catal Commun, 2007, 8: 673

[13] Kantevari S, Bantu R, Nagarapu L. J Mol Catal A, 2007, 269: 53

[14] Soliman H A, Salama T A. Chin Chem Lett, 2013, 24: 404

[15] Khazaei A, Reza Moosavi-Zare A, Mohammadi Z, Zare A, Khakyzadeh V, Darvishi G. RSC Adv, 2013, 3: 1323

[16] Zhou Z Q, Deng X C. J Mol Catal A, 2013, 367: 99

[17] Mulakayala N, Murthy P V N S, Rambabu D, Aeluri M, Adepu R, Krishna G R, Reddy C M, Prasad K R S, Chaitanya M, Kumar C S, Rao M V B, Pal M. Bioorg Med Chem Lett, 2012, 22: 2186

[18] Das B, Kashanna J, Kumar R A, Jangili P. Synth Commun, 2012, 42: 2876

[19] Ilangovan A, Muralidharan S, Sakthivel P, Malayappasamy S, Karuppusamy S, Kaushik M P. Tetrahedron Lett, 2013, 54: 491

[20] Rostamizadeh S, Amani A M, Mahdavinia G H, Amiri G, Sepehrian H. Ultrason Sonochem, 2010, 17: 306

[21] Sivaguru P,Lalitha A. Chin Chem Lett, 2014, 25: 321

[22] Esmaeilpour M, Javidi J, Dehghani F, Nowroozi Dodeji F. New J Chem, 2014, 38: 5453

[23] Oskooie H A, Tahershamsi L, Heravi M M, Baghernejad B. E J Chem, 2010, 7: 717

[24] Hua G P, Li T J, Zhu S L, Zhang X J. Chin J Org Chem (华国平, 李 团结, 朱松否, 章晓镜. 有机化学), 2005, 25: 716

[25] Simon M O, Li C J. Chem Soc Rev, 2012, 41: 1415

[26] Shekouhy M. Catal Sci Technol, 2012, 2: 1010

[27] Pan X Y, Lu C F, Nie J Q, Chen Z X, Yang G C, Dong N G, Shi J W. Catal Commun, 2014, 53: 72

[28] Mohammad N R, Yasamin B. Appl Catal A, 2014, 469: 183

[29] Wang Y L, Luo J, Liu Z L. Appl Organomet Chem, 2013, 27: 601 


\section{Graphical Abstract}

Chin. J. Catal., 2015, 36: 1249-1255 doi: 10.1016/S1872-2067(15)60888-9

Efficient synthesis of 1,8-dioxo-octahydroxanthenes catalyzed by $\beta$-cyclodextrin grafted with butyl sulfonic acid in aqueous media

Kai Gong *, Hualan Wang, Shuxin Wang, Ying Wang, Jinghua Chen

Jiangnan University; Hangzhou Normal University

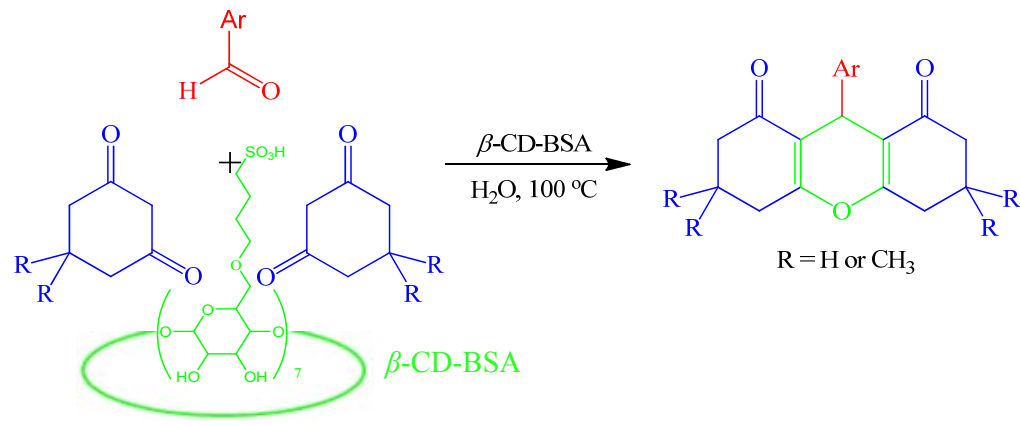

$\beta$-Cyclodextrin has been functionalized with butyl sulfonic acid to give an efficient eco-friendly catalyst ( $\beta$-CD-BSA) for the synthesis of 1,8-dioxo-octahydroxanthenes via the one-pot condensation of aromatic aldehydes and active methylene carbonyl compounds in aqueous media.

[30] Ishii D, Ohashi C, Hayashi H. Green Chem, 2014, 16: 1764

[31] Bai L, Wyrwalski F, Lamonier J F, Khodakov A Y, Monflier E, Ponchel A. Appl Catal B, 2013, 138-139: 381

[32] Zhang G F, Luan Y X, Han X W, Wang Y, Wen X, Ding C R, Gao J R. Green Chem, 2013, 15: 2081

[33] Liu H M, Li Y M, Wu H, Liu J X, He D H. Chin J Catal (刘会敏, 李宇 明, 吴吴, 刘佳雄, 贺德华. 催化学报), 2015, 36: 283

[34] Hapiot F, Bricout H, Menuel S, Tilloy S, Monflier E. Catal Sci Technol, 2014, 4: 1899
[35] Wu J, Du X L, Ma J, Zhang Y P, Shi Q C, Luo L J, Song B A, Yang S, Hu D Y. Green Chem, 2014, 16: 3210

[36] Asghari S, Tajbakhsh M, Kenari B J, Khaksar S. Chin Chem Lett, 2011, 22: 127

[37] Song A J, Wang J H, Liu C D, Deng L H. Chin Sci Bull (宋爱晶, 王建华, 刘春东, 邓林红. 科学通报), 2009, 54: 1362

[38] Blach P, Landy D, Fourmentin S, Surpateanu G, Bricout H, Ponchel A, Hapiot F, Monflier E. Adv Synth Catal, 2005, 347: 1301

[39] Kiasat A R, Nazari S. Catal Sci Technol, 2012, 2: 1056

\section{水相体系中 $\boldsymbol{\beta}$-环糊精-丁磺酸催化合成氧杂葱二酮衍生物

\author{
巩 凯 ${ }^{\mathrm{a},}{ }^{*}$, 王华兰 ${ }^{\mathrm{b}}$, 王舒馨 ${ }^{\mathrm{a}}$, 王 颖 ${ }^{\mathrm{a}}$, 陈敬华 ${ }^{\mathrm{a}}$ \\ ${ }^{a}$ 江南大学药学院, 江苏无锡 214122 \\ ${ }^{\mathrm{b}}$ 杭州师范大学有机硅教育部重点实验室, 浙江杭州 311121
}

摘要: 多组分反应是指三个或三个以上反应物在同一反应容器里形成一个新的、包括所有反应物主要部分的产物. 多组分反应因 具有操作简单、效率高和原子经济性好等优点而引起化学家和药物化学工作者的极大兴趣, 成为有机合成发展趋势之一. 9-芳基2,3,4,5,6,7-六氢- $2 H$-氧杂葱-1,8-二酮衍生物是由芳香醛和 1,3 -环已二酮化合物的多组分缩合反应制备. 通常在Lewis酸或Brönsted 酸催化下进行反应, 常用的催化剂有对十二烷基苯磺酸、Amberlyst- $1 、 \mathrm{I}_{2} 、 \mathrm{MCM}-41-\mathrm{SO}_{3} \mathrm{H} 、 \mathrm{HClO}_{4}-\mathrm{SiO}_{2}$ 、离子液体 (如 $\left[\mathrm{Et}_{3} \mathrm{NH}\right]\left[\mathrm{HSO}_{4}\right]$ )、纳米 $\mathrm{TiO}_{2}$ 和纤维素-磺酸等, 微波和超声波等技术也用于该反应. 这些方法虽取得一定进展, 但仍然存在反应时 间较长和产率较低等缺点. 因此, 开发与研究氧杂葱二酮衍生物的绿色合成方法显得非常必要.

$\beta$-环糊精是由 7 个葡萄糖经 1,4 -苷键连接而成的环状化合物, 7 个伯醇羟基位于空洞小的一端, 14 个仲醇排列在空洞大的一端, 形成空洞外部和入口处富有亲水性而空洞内部呈疏水性的特性. 由于这一独特性能, $\beta$-环糊精及其衍生物被作为相转移催化剂应 用于有机合成反应, 如氧化反应、还原反应、环加成反应及偶联反应. 对 $\beta$-环糊精进行功能化修饰是拓展 $\beta$-环糊精在有机合成反 应中应用的有效方法之一。

本文采用丁磺酸基功能化修饰 $\beta$-环糊精, 得到 $\beta$-环糊精-丁磺酸 $(\beta$-CD-BSA), 探讨了其作为酸性催化剂在芳香醛和 $1,3-$-环己二 酮(或二甲酮)制备氧杂葱二酮衍生物反应中的应用. 首先, $\beta$-环糊精与丁磺酸内酯反应, 生产磺丁基醚- $\beta$-环糊精, 再经过酸性离子 交换树脂, 得到 $\beta$-CD-BSA, 采用红外光谱(FT-IR) 和 ${ }^{1} \mathrm{H}$ NMR表征催化剂. 结果表明, 磺酸丁基成功嫁接到 $\beta$-环糊精上, 经 ${ }^{1} \mathrm{H}$ NMR 图谱分析, $\beta$-CD-BSA的磺酸丁基平均取代度为 7. 以苯甲醛和二甲酮反应为模型反应, 探讨了反应溶剂和催化剂用量等因素对反 应性能的影响, 得到最优反应工艺条件为: 以 $\mathrm{H}_{2} \mathrm{O}$ 为溶剂, 反应温度 $100{ }^{\circ} \mathrm{C}$, 催化剂用量 $1 \mathrm{~mol} \%$. 探讨了反应底物适用性, 采用不 同取代基的芳香醛与 1,3 -环已二酮(或二甲酮)反应, 制备了一系列氧杂葱二酮衍生物. 结果表明, 无论芳香醛苯环上连接吸电子基 
团还是供电子基团, 都能顺利发生反应并得到相应目标化合物, 反应时间为 $15-60 \mathrm{~min}$, 产率为 $88 \%$ - $97 \%$. 同时, 与芳香醛上连有 供电子基团相比, 当芳香醛上连有吸电子基团时, 其反应速度更快, 反应时间更短, 产率相对较高. 与文献报道方法相比, 本文构 建的催化反应体系具有更高的催化活性和较高的反应产率. 基于上述反应现象, 结合相关文献, 探讨了该反应可能的反应机理. 本文还以对硝基苯甲醛和二甲酮反应为模型反应, 探讨了 $\beta$-CD-BSA循环回收使用性能. 当反应结束后, 加入少量水, 过滤得到固 体产物, 滤液经干燥回收催化剂, 不经进一步处理即可用于下一次反应, 当催化剂循环使用 5 次时, 反应产率由 $95 \%$ 降至 $90 \%$. 可 见, 该催化剂回收方法简单, 催化剂具有良好的稳定性.

综上所述, 本文构建了 $\beta$-CD-BSA $/ \mathrm{H}_{2} \mathrm{O}$ 催化反应体系, 制备了一系列氧杂葱二酮衍生物, 该催化反应体系具有良好的催化性能 和通用性, 该方法操作简单, 反应时间短, 产率高, 是一个制备氧杂葱二酮衍生物的绿色合成方法.

关键词: 一锅法合成; 酸催化; $\beta$-环糊精-丁磺酸; 1,8 -氧杂葱二酮衍生物; 水相反应

收稿日期: 2015-04-07. 接受日期: 2015-05-09. 出版日期: 2015-08-20.

*通讯联系人. 电话/传真: (0510)85197769; 电子信箱: kingong222@163.com

基金来源：国家自然科学基金(51303069); 江南大学自主科研基金(JUSRP11236).

本文的英文电子版由Elsevier出版社在ScienceDirect上出版(http://www.sciencedirect.com/science/journal/18722067). 